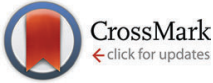

Cite this: Phys. Chem. Chem. Phys., 2015, 17, 22699

Received 21st May 2015 Accepted 22nd July 2015

DOI: $10.1039 / \mathrm{c} 5 \mathrm{cp} 02942 \mathrm{~b}$

www.rsc.org/pccp

\title{
Role of temperature in the recombination reaction on dye-sensitized solar cells $\dagger$
}

\author{
J. Maçaira, I. Mesquita, L. Andrade and A. Mendes*
}

\begin{abstract}
The performance of photovoltaic (PV) devices as a function of temperature is crucial for technical development and for accurate commercial information. Along with solar irradiance, temperature is the most important operating factor of the PV device performance. Normally, it is widely accepted that dye sensitized solar cells (DSC) show minimal energy efficiency dependence with temperature $\left(20-60{ }^{\circ} \mathrm{C}\right)$. The energy efficiency in DSCs depends on the light absorption, charge transport (ohmic resistances) and recombination rates. In this study, the recombination reaction kinetics was studied within a wide temperature range. A unique laser assisted sealing technique that allows studying the temperature effect between $-5{ }^{\circ} \mathrm{C}$ and $105{ }^{\circ} \mathrm{C}$ without electrolyte leakage or external contamination was used. To the best of our knowledge, this is the highest operating temperature ever considered in kinetic studies of liquid state DSCs. The electrochemical reaction between electrons and triiodide/iodide ions was shown to be the most important factor for determining the energy efficiency of DSCs as a function of temperature. It was concluded that the activation energy of the recombination reactions depends on the interface where it happens $-\mathrm{TiO}_{2}$ /electrolyte and $\mathrm{SnO}_{2}-\mathrm{F} /$ electrolyte - and on the temperature. It was found that in addition to temperature having a deep influence on the recombination reaction rate, the energy of the injecting electron is also critical. These conclusions should provide solid ground for further developments in the DSCs and perovskite solar cells, and allow a better comparison of the energy efficiency of different PV technologies over a range of operating temperatures.
\end{abstract}

\section{Introduction}

Direct conversion of solar light to electricity is becoming a winning strategy with photovoltaic (PV) electricity cost, already below the grid in several countries. ${ }^{1}$ However, high production costs prevent the current PV solutions from standing out as a real energy production alternative. Dye-sensitized solar cells (DSCs) are an important type of thin-film photovoltaics due to their potential for low-cost fabrication and versatile applications, and they are already being looked upon as a future alternative to silicon PV devices. The presumed cost/effectiveness of DSCs makes them worth investing. ${ }^{2-4}$ Regardless of the countless efforts and enormous amount of publications, ${ }^{5}$ the maximum photo conversion efficiency $(\eta)$ of DSCs has stagnated at about $12 \%{ }^{6-8}$ over the last ten years. The best conversion efficiency of a DSC device was achieved using porphyrin-sensitizers coupled with cobalt(II/III) based redox electrolyte under simulated air mass 1.5 global sunlight (AM 1.5G) conditions $\left(100 \mathrm{~mW} \mathrm{~cm}^{-2}\right) .{ }^{9}$ Recently, a lead halide perovskite absorber combined with a

LEPABE - Faculdade de Engenharia, Universidade do Porto, rua Dr. Roberto Frias, 4200-465, Portugal.E-mail: mendes@fe.up.pt

$\dagger$ Electronic supplementary information (ESI) available. See DOI: 10.1039/ c5cp02942b solid hole transporting material (HTM) have ramped up the efficiencies from $14.1 \%^{10}$ in 2013 to an impressive certified result of $20.1 \%$ in the early of $2015 .{ }^{11,12}$ Although DSCs and perovskite solar cells (PSCs) meet the efficiency criteria for market implementation, there is a striking lack of stability studies needed for technology industrialization. ${ }^{13-21}$

Along with solar irradiance, temperature is probably the most important outdoor variable that affects the conversion efficiency of PV devices. However, temperature studies on DSCs are scarce and usually limited to temperatures up to $60{ }^{\circ} \mathrm{C}$. ${ }^{22-28}$ Moreover, the glass substrates normally used to assemble DSCs are poor thermal conductors, resulting in a lower real temperature value than anticipated by typical temperature control setups; moreover, solar simulators irradiance also increase the glass temperature (absorbance of $c a$. 20\%), which makes it difficult to have good control over the temperature analysis. To the best of our knowledge, all the reported studies have not considered these effects. Therefore, due to lack of accuracy, our knowledge pertaining the effect of temperature on DSCs performance remains just qualitative.

In general, conduction band shift of the $\mathrm{TiO}_{2}$ film and recombination and charges transport kinetics in a DSC are the phenomena that depend on temperature for its performance. ${ }^{22,26-28}$ Charge recombination corresponds to the undesirable reaction of generated electrons with electrolyte species, ultimately ruling 
the final performance of DSCs. This reaction involves either free conduction band electrons or electrons trapped in the lower energy states. ${ }^{29}$ Electronic traps are sites within the semiconductor (energetically localized in the bandgap) that restrict the movement of electrons. They are caused either by chemical impurities, morphological defects or imperfections in the regular spacing of the atoms. ${ }^{30}$ The driving force for recombination is related to the energy level, wherein the electrons are located in $\mathrm{TiO}_{2}$, and temperature, both of which are related to the rate constant, $k_{\mathrm{r}}(T)$, and the electron concentration. ${ }^{31,32}$ As $V_{\mathrm{OC}}$ changes, the Fermi level $\left(E_{\mathrm{F}}\right)$ in $\mathrm{TiO}_{2}$ moves towards or away from the conduction band edge $\left(E_{\mathrm{CB}}\right)$; when the Fermi level moves up, the respective electron traps below are filled. Taking this into consideration, it can be expected that the activation energy $\left(E_{\mathrm{a}}\right)$ of recombination is proportional to $\left(E_{\mathrm{CB}}-E_{\mathrm{F}}\right){ }^{33}$ However, recombination processes do not take place only at $\mathrm{TiO}_{2}$ /electrolyte interface; they can occur by the reaction of electrolyte species with generated electrons that can be located either in the $\mathrm{TiO}_{2}$ photoelectrode or in the transparent conductive oxide (TCO), as shown in Fig. 1. This information is well known in the DSC community, and several passivation methodologies have been developed to decrease recombination. ${ }^{34-39}$ The most successful strategies include the use of blocking layers over the TCO film; ${ }^{37,38,40-42}$ the use of $\mathrm{TiO}_{2}$ sols applied to the mesoporous $\mathrm{TiO}_{2}$ layer; ${ }^{43,44}$ and more recently, the use an encapsulation layer by atomic layer deposition (ALD) of $\mathrm{TiO}_{2}$ applied over the dyed semiconductor. ${ }^{39}$ These approaches were developed to prevent recombination by different mechanisms, and although proven effective, studies that link temperature effects with recombination rates are rare.

Usually, the recombination kinetics is characterized by electrochemical impedance spectroscopy (EIS) and its magnitude can be analysed by fitting the experimental data to appropriate electrical analogues. ${ }^{45,46}$ The electron lifetime $\left(\tau_{\mathrm{e}^{-}}\right)$can be extracted and thus the recombination rate constant $\left(k_{\mathrm{r}}=1 / \tau_{\mathrm{e}^{-}}\right)$ in the solar cell can be calculated. This powerful analytical technique has proven invaluable during the DSC technological development; unfortunately, per se, it does not allow distinguishing different recombination reaction pathways, i.e. at $\mathrm{TiO}_{2}$ or $\mathrm{SnO}_{2}-\mathrm{F}$ interface - Fig. 1b.
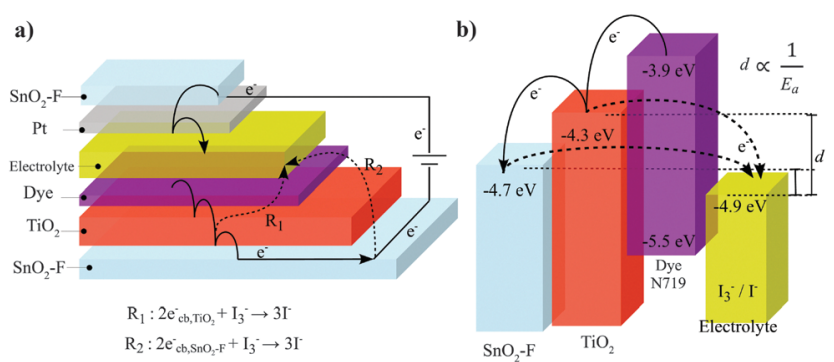

Fig. 1 (a) Schematic of the working principles at a dye sensitized solar cell; and (b) diagram of energy levels of each functional layer in the DSC. The full arrows represent electron pathways through the device; the dashed arrows represent the main loss reaction mechanisms due to recombination through $\mathrm{TiO}_{2}$ or $\mathrm{SnO}_{2}-\mathrm{F}$ interfaces $\left(\mathrm{R}_{1}\right.$ and $\mathrm{R}_{2}$, respectively). The actual energy levels may change upon assembling.
The present study aims to understand and quantify the recombination at the $\mathrm{TiO}_{2}$ /electrolyte and FTO/electrolyte interfaces and their dependence on temperature. This should provide valuable information for the development of more efficient materials and solar cell architectures and to better predict the temperature influence on the PV output of future commercial applications. An experimental setup was developed that accurately controls the inner temperature of DSC devices, allowing their characterization as a function of temperature. Laser assisted glass sealing reported elsewhere ${ }^{47,48}$ was used to make the solar cells hermetic, even up to the boiling point of the electrolyte; the setup and sealing process allows very accurate characterizing results between set points of $-5{ }^{\circ} \mathrm{C}$ and $105{ }^{\circ} \mathrm{C}$. The temperature influence in the $I-V$ curves as well as in the electrochemical kinetics of the solar cell was determined and is discussed.

An experimental methodology that distinguishes the recombination occurring at $\mathrm{TiO}_{2}$ /interface from recombination occurring at TCO $\left(\mathrm{SnO}_{2}-\mathrm{F}\right)$ interface was developed; to do so, the TCO area exposed to the electrolyte was progressively increased to deliberately cause changes in the recombination rate constant. This allows quantification of the temperature influence for both recombination pathways and its implications in solar cells operation and respective architecture design.

\section{Materials and methods}

\section{Laser sealed DSCs and half-cell fabrication}

In the present study, two types of devices were fabricated: DSCs and half-cells, as shown in Fig. 2 and Fig. S1 (ESI $\dagger$ ). DSCs are made of two electrodes: the photo electrode (PE) and the counter electrode (CE); the electrolyte in between contains the iodide/triiodide redox pair. $\mathrm{PE}$ and $\mathrm{CE}$ are each applied to glass coated with a transparent conducting oxide (TCO); the PE includes a mesoporous $\mathrm{TiO}_{2}$ film sensitized with a dye responsible for light absorption. The CE consists of a nanometric platinum

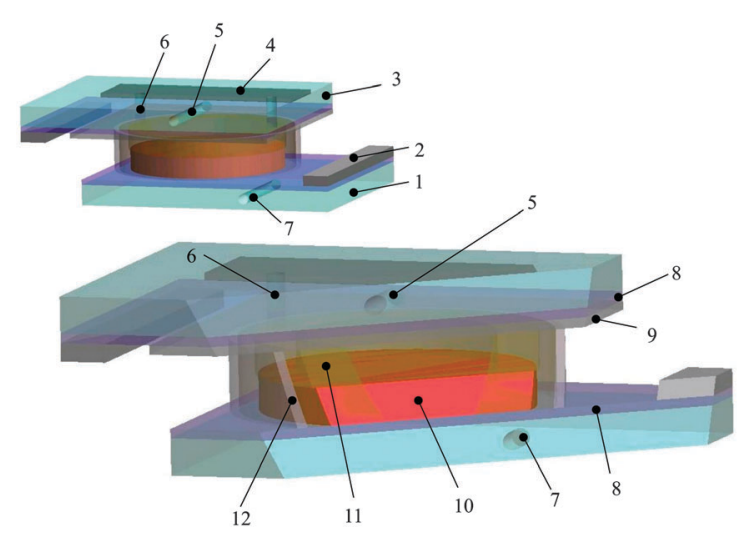

Fig. 2 Schematic of the manufactured DSC device (not in scale): 1 - photoelectrode glass; 2 - electrical contact; 3 - counter-electrode glass; 4 - filling hole cover; 5 - drilled hole for temperature measurement, $T_{2} ; 6$ - filling hole; 7 - drilled hole for temperature measurement, $T_{1}$; 8 - TCO; 9 - platinum catalyst; $10-\mathrm{TiO}_{2}$ with adsorbed sensitizer; 11 - electrolyte; 12 - glass frit sealing. 
layer applied to the TCO surface that is responsible for catalysing the reduction of triiodide to iodide. A half-cell configuration consisting two identical TCO glasses coated with the relevant material separated the electrolyte. They mimic the phenomena in a DSC allowing the evaluation of CE and electrolyte behaviours without the interference of the sensitized porous $\mathrm{TiO}_{2}$ layer. In the present study, they were used to study the electrochemical reactions of electrons with electrolyte species over a specific interface. Half-cells made with thin films of $\mathrm{SnO}_{2}-\mathrm{F}, \mathrm{Pt}$, and $\mathrm{TiO}_{2}$ were assembled to study the recombination reaction as a function of temperature. The preparation of both devices (DSCs and half-cells) is described as follows.

Photoelectrodes were prepared on $2.2 \mathrm{~mm}$ thick, $7 \Omega \square^{-1}$ $\mathrm{SnO}_{2}-\mathrm{F}$ (FTO) coated glass substrates from Solaronix ${ }^{\circledR}$. First, the glasses were washed sequentially with a detergent solution (Alconox ${ }^{\circledR}$, VWR) in an ultrasonic cleaner (Amsonic TTC) at $55{ }^{\circ} \mathrm{C}$ for $15 \mathrm{~min}$, followed by ultrasonic cleaning in deionized water at room temperature, rinsed with ethanol and dried in air at $50{ }^{\circ} \mathrm{C}$. The samples were then coated with a porous $\mathrm{TiO}_{2}$ layer by screen-printing a commercial $\mathrm{TiO}_{2}$ paste (Ti-Nanoxide T/SP from Solaronix ${ }^{\circledR}$ ), followed by drying at $100{ }^{\circ} \mathrm{C}$ for 5 minutes. To control the final thickness of the transparent layer of $\mathrm{TiO}_{2}$, the screen-printing and drying procedures were repeated as necessary to achieve the desired thickness $(12 \mu \mathrm{m}$-thick photoelectrodes were obtained with three screen-printing cycles). Samples were annealed at $475{ }^{\circ} \mathrm{C}$ for $15 \mathrm{~min}$ in an infrared electrical oven (Nabertherm Gmbh model GF75). After firing, the samples were treated with a $40 \mathrm{mM} \mathrm{TiCl}_{4}$ aqueous solution at $70{ }^{\circ} \mathrm{C}$ for 20 minutes before being sintered at $475{ }^{\circ} \mathrm{C}$ for $30 \mathrm{~min}$. In the cells, wherein the blocking layer is required, a thin and compact layer of $\mathrm{TiO}_{2}$ above the FTO layer was applied by immersing the FTO glasses in a $40 \mathrm{mM} \mathrm{TiCl}_{4}$ aqueous solution at $70{ }^{\circ} \mathrm{C}$ for 20 minutes; after washing with water and ethanol, the samples were dried with a nitrogen flow. The counter electrodes, prepared on the same type of glass substrates and cleaned as described before, were drilled previously with two holes, $1 \mathrm{~mm}$ in diameter. A commercial platinum based paste (Platisol T/SP from Solaronix ${ }^{\circledR}$ ) was applied on the glass substrate by screen-printing followed by annealing at $400{ }^{\circ} \mathrm{C}$ for 15 minutes.

Both in the DSCs and half cells devices, the two electrodes were assembled and sealed using a laser assisted glass frit method. ${ }^{47}$ To control the exposed $\mathrm{SnO}_{2}-\mathrm{F}$ area to electrolyte, the glass frit-sealing perimeter was varied from 5 to $12 \mathrm{~mm}$ (see Fig. 11) without changing the total distance to the electrical contact; this way the electron lifetime can be controlled without changing the series resistances. Dye adsorption in a porous $\mathrm{TiO}_{2}$ photoelectrode was obtained by recirculating a dye solution (0.5 mM N719 and 5 M chenodeoxycholic acid in ethanol) for 12 hours using a peristaltic pump (Ismatec ${ }^{\circledR}$, Reglo Digital MS-4/8), followed by ethanol rinsing, nitrogen drying, electrolyte filling (high stability iodolyte Z-150 from Solaronix ${ }^{\circledR}$ ) and hole sealing by a combination of thermoplastic sealant (Surlyn ${ }^{\circledR}$, Dupont) and high temperature resistant resin (Pattex ${ }^{\circledR}$ Nural 22 from Henkel). Solder bus bars and electrical wires were applied to the FTO surface of the photo and counter-electrodes, respectively, using an ultrasonic soldering unit (MBR electronics model USS-9210); the soldered bus bars were protected by high temperature resistant resin to prevent corrosion caused by heat and moisture. The manufacture process described produced devices resistant at least to $120{ }^{\circ} \mathrm{C}$ without electrolyte leakage. The manufactured DSCs had an energy efficiency between 5\% and $6 \%\left(25^{\circ} \mathrm{C}, 100 \mathrm{~mW} \mathrm{~cm}{ }^{-2}, 1.5\right.$ air mass filter $)$, which is typical for devices prepared with a non-volatile electrolyte (Iodolyte Z150-Solaronix) based on methoxypropionitrile (MPN), known to produce stable but less efficient devices than that with acetonitrile based electrolytes.

\section{Experimental setup}

The experimental $I-V$ characteristics were obtained in a setup equipped with a $150 \mathrm{~W}$ xenon light source (Oriel class A solar simulator, Newport, USA) with variable light intensity from 10 to $100 \mathrm{~mW} \mathrm{~cm} \mathrm{~cm}^{-2}$ (0.1 to 1 sunlight intensity), and using a 1.5 air mass filter (Newport, USA). The simulator was calibrated using a single crystal Si photodiode (Newport, USA). The $I-V$ characteristics of the solar cell were obtained by applying an external potential load and measuring the generated photocurrent using an AUTOLAB electrochemical station. This station was also used to characterize the cells through EIS. The frequency range for EIS measurements was from $100 \mathrm{kHz}$ to $0.05 \mathrm{~Hz}$ with an AC modulation signal of $10 \mathrm{mV}$. EIS measurements were carried out in dark and at the open circuit potential measured at $25{ }^{\circ} \mathrm{C}$ $\left(V_{\mathrm{OC}}, 25{ }^{\circ} \mathrm{C}\right)$ for DSCs and at $0 \mathrm{~V}$ for half-cells. The operation temperature of the solar cell was controlled using an in-house made experimental setup, shown in Fig. 3 and Fig. S2 (ESI $\dagger$ ), based on a peltier device (Marlow Industries, model RC12-6) connected to a Keithley DC power supply (Model 2425C). A PID algorithm was run on a National Instruments LabVIEW application. Four K-type thermocouples were placed in different locations: in a drilled axial hole in the photoelectrode glass $\left(T_{1}\right)$, in the counter electrode glass $\left(T_{2}\right)$ and at aluminum slabs connected

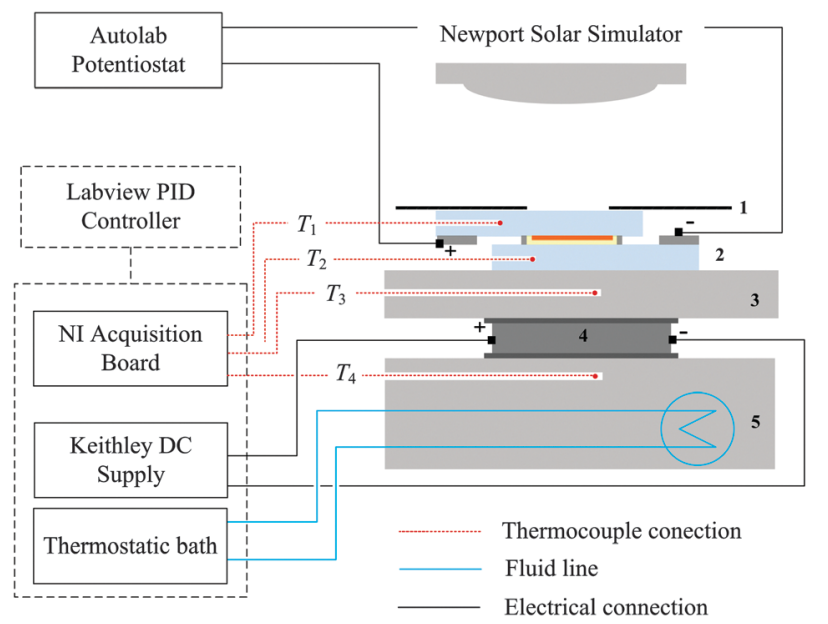

Fig. 3 Experimental setup used for temperature control of an under illumination DSC between $-5{ }^{\circ} \mathrm{C}$ and $105^{\circ} \mathrm{C}$. 1 - Thermal insulator black mask; 2 - DSC; 3 - aluminum slab; 4 - peltier device; 5 - aluminum slab with drilled thermal fluid circuit. 
to the cold and hot side ( $T_{3}$ and $T_{4}$, respectively) of the thermoelectrical element (peltier module). All heat transfer interfaces were filled with a thermal conducting paste to maximize heat transfer. When a potential difference is applied to the thermoelectrical element (4), a temperature difference is created between both sides $\left(T_{3}\right.$ and $\left.T_{4}\right)$ of the peltier device.

Using a PID algorithm, it is possible to accurately control the temperature at the DSC $\left(T_{3}\right)$. The heat-dissipating surface $\left(T_{4}\right)$ of the peltier device was cooled using a thermal fluid from a thermostatic bath (Julabo model ME, Germany) (5). Under illumination, and without temperature control, the temperature inside the DSC can increase more than $10{ }^{\circ} \mathrm{C}$ in a few minutes. Fig. S3 (ESI $\dagger$ ) presented in the supporting information shows that when the temperature control is turned on, the system immediately responds to correct the temperature to the desired set-point.

Fig. 4 show the temperature readings of a DSC device under illumination. Typically the temperature difference between the counter-electrode side $\left(T_{2}\right)$ and the peltier cold side $\left(T_{3}\right)$ is less than $1{ }^{\circ} \mathrm{C}$, as the heat conduction of the aluminium slab is quite high. However, the temperature difference between the glass substrates of both electrodes of the solar cell can be
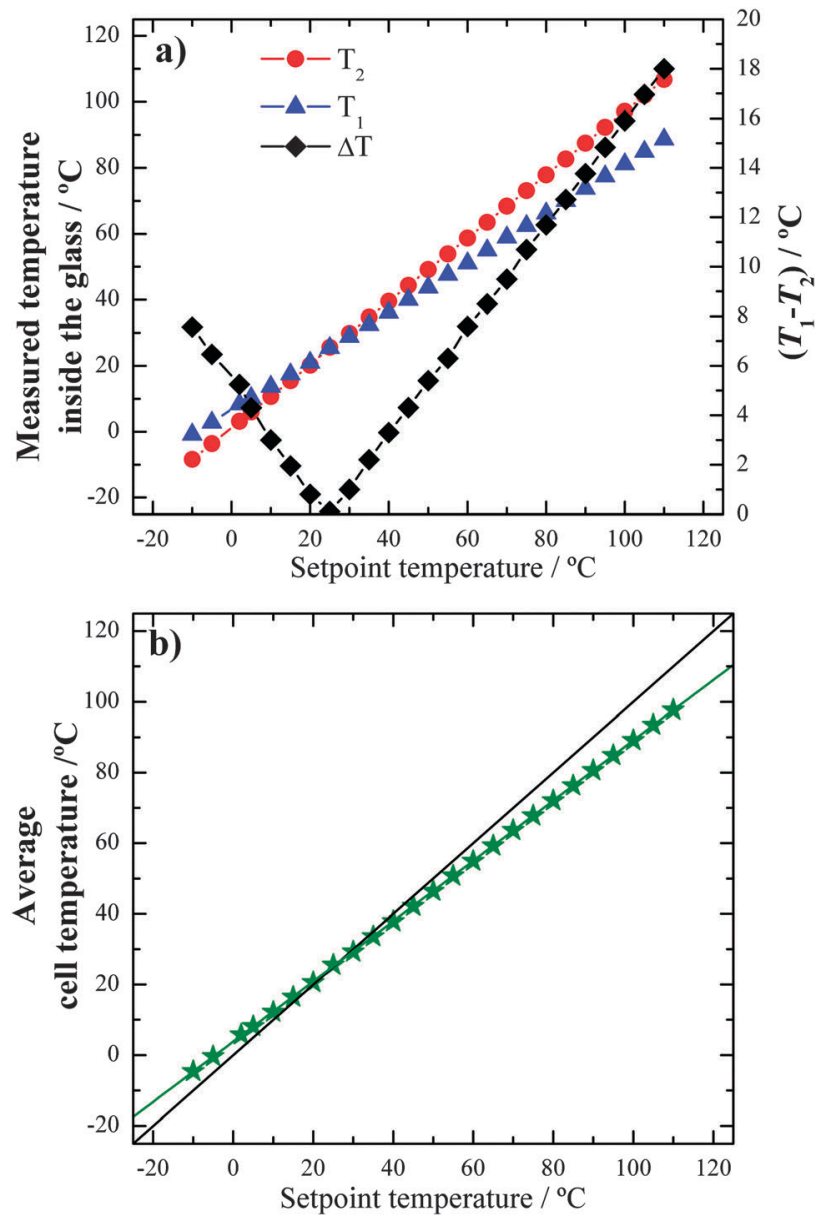

Fig. 4 Temperature values from: (a) $T_{1}$ (photoelectrode), $T_{2}$ (counter electrode), calculated temperature difference between electrodes; and (b) average cell temperature versus set point temperature. relatively high, especially at low or high temperatures. Above a set point of $50{ }^{\circ} \mathrm{C}$, the temperature gap starts widening and it can go up to $20{ }^{\circ} \mathrm{C}$ at $110{ }^{\circ} \mathrm{C}$; this illustrates the low thermal conductivity of the glass substrates.

Although the gap between both the electrodes is filled with a liquid electrolyte, there is always a temperature gradient inside the cell, particularly at temperatures far from room temperature. This highlights the importance of taking correct temperature readings when analysing the temperature effect. In all the results presented in this study, temperature was corrected to the average cell temperature calculated by the readings taken inside both glass electrodes of the solar cell $\left(T_{1}\right.$ and $\left.T_{2}\right)$.

\section{Results and discussion}

\section{Temperature influence in DSC performance}

$I-V$ and EIS analysis were conducted in several batches of DSCs, from set point temperatures ranging from $-5{ }^{\circ} \mathrm{C}$ to $105{ }^{\circ} \mathrm{C}$. $V_{\mathrm{OC}}$, $J_{\mathrm{SC}}, \mathrm{FF}$ and $\eta$ were read for each temperature using the average of three devices; these parameters were used to characterize the performance of the cells and are called the performance parameters. The photoconversion efficiency $(\eta)$ of the solar cell was determined by its current-voltage characteristics, specifically the open-circuit photovoltage $\left(V_{\mathrm{OC}}\right)$, the photogenerated current density measured under short-circuit conditions $\left(J_{\mathrm{SC}}\right)$, the intensity of incident light $\left(I_{\mathrm{S}}\right)$ and the fill factor of the cell (FF). The current and voltage output of the DSC result from a balance between the charge generation flux and the recombination flux. The effect of temperature in the $I-V$ curves of a typical DSC batch is presented in Fig. 5. The $I-V$ curves have been normalized with respect to $V_{\text {OC }}$ and $J_{\text {SC }}$ obtained at $25{ }^{\circ} \mathrm{C}$. As the temperature increases, there is a decrease in both $V_{\mathrm{OC}}$ and $J_{\mathrm{SC}}$ values, leading to a decrease in performance. Fig. 6 shows the performance parameters, normalized by the corresponding values obtained at $25{ }^{\circ} \mathrm{C}$, as a function of temperature. FF appears to be the only parameter that slightly increased with temperature. It can be clearly seen that there are different decrease rates of $V_{\mathrm{OC}}$ and $J_{\mathrm{SC}}$ as a function of the temperature; the short circuit current has a higher decrease with temperature than the open-circuit voltage. $\mathrm{FF}$ is the ratio between the maximum power density and the product of $V_{\mathrm{OC}}$ and $J_{\mathrm{SC}}$. Because $V_{\mathrm{OC}}$ decreases with temperature at a higher rate than $J_{\mathrm{SC}}$, there is a higher FF for higher temperatures. In this particular batch of cells, the efficiency is approximately constant with temperature up to $c a .50{ }^{\circ} \mathrm{C}$. Considering $25{ }^{\circ} \mathrm{C}$ as the reference temperature, at $50{ }^{\circ} \mathrm{C}$ these cells retained about $91 \%$ of the efficiency; at $70{ }^{\circ} \mathrm{C}$, $70 \%$ and at $100{ }^{\circ} \mathrm{C}$, only ca. $30 \%$.

To determine if this loss of efficiency was reversible, the analysis was repeated at $25{ }^{\circ} \mathrm{C}$ after the samples underwent the highest temperature analysis (Fig. S4 and Table S1 in ESI $\dagger$ ). The performance of the DSCs showed excellent temperature resistance: there was a decrease in $J_{\mathrm{SC}}$, but an increase in the $\mathrm{FF}$ that resulted in a higher efficiency $(5.83 \%$ vs. $6.01 \%$ before and after the tests, respectively). The $V_{\text {OC }}$ showed no meaningful changes ( $0.773 \mathrm{~V} v s .0 .778 \mathrm{~V}$ before and after the tests, respectively). 


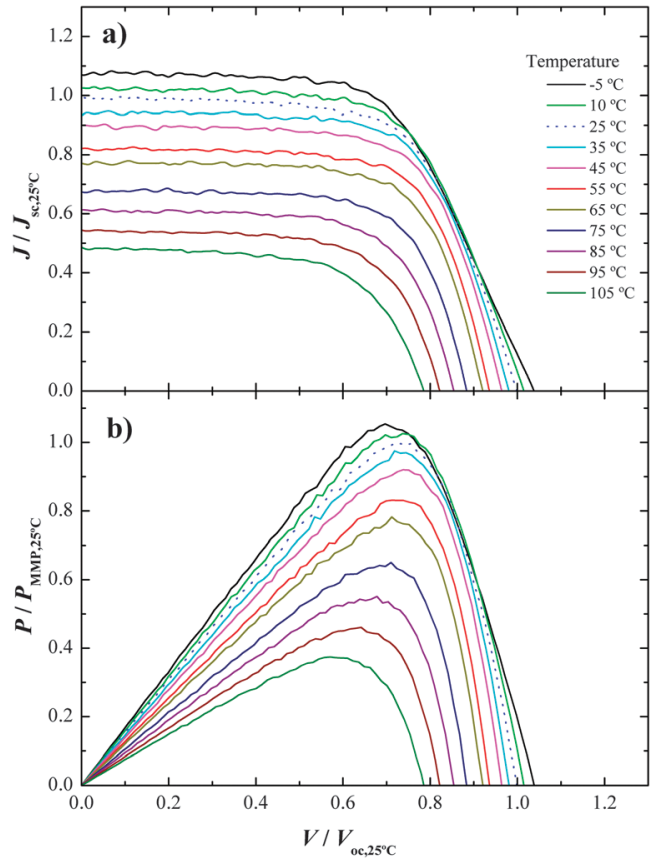

Fig. 5 (a) $I-V$ and (b) power curves normalized to the corresponding values at $25^{\circ} \mathrm{C}$ as a function of temperature.

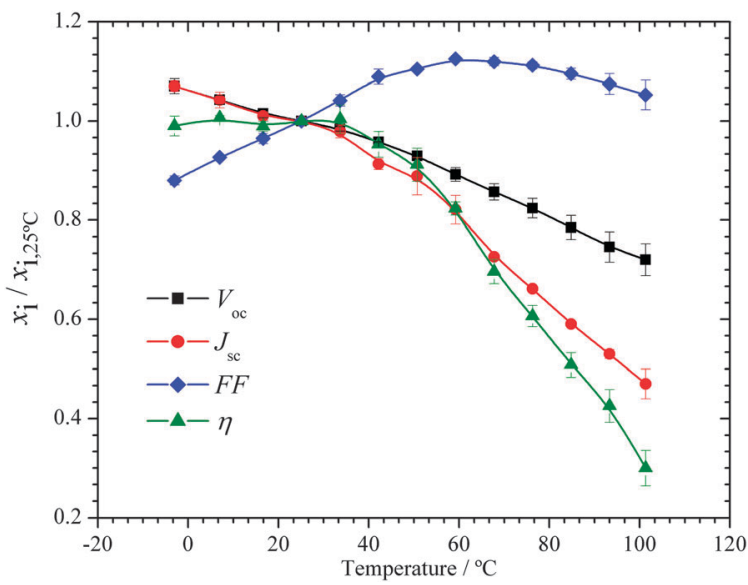

Fig. 6 Performance parameters normalized to the corresponding values $25^{\circ} \mathrm{C}$ values $\left(V_{\mathrm{OC}}, 25^{\circ} \mathrm{C}=0.77 \mathrm{~V} ; \mathrm{J}_{\mathrm{SC}}, 25^{\circ} \mathrm{C}=9.5 \mathrm{~mA} \mathrm{~cm}^{-2}\right)$, as a function of the operating temperature. Lines were added for readability.

The DSCs also showed less than 15\% total efficiency degradation after over 1000 hours of storage at room temperature under dark conditions, after conducting the temperature tests, as shown in Fig. S5 (ESI $\dagger$ ).

This was mainly due to a decrease in $J_{\mathrm{SC}}$, which in turn is probably caused by dye desorption from $\mathrm{TiO}_{2}$ film occurring at high temperatures, a known phenomenon with the $\mathrm{N} 719 / \mathrm{I}_{3}{ }^{-}$ system $;{ }^{15,21}$ the $V_{\mathrm{OC}}$ and FF showed remarkable stability with no particular degradation. These results show that in the analysis conditions described and up to $100{ }^{\circ} \mathrm{C}$, there is no internal degradation of the solar cell components, which attests the thermal resistance and sealing quality of the prepared DSCs; this allows a correct analysis of the temperature influence.
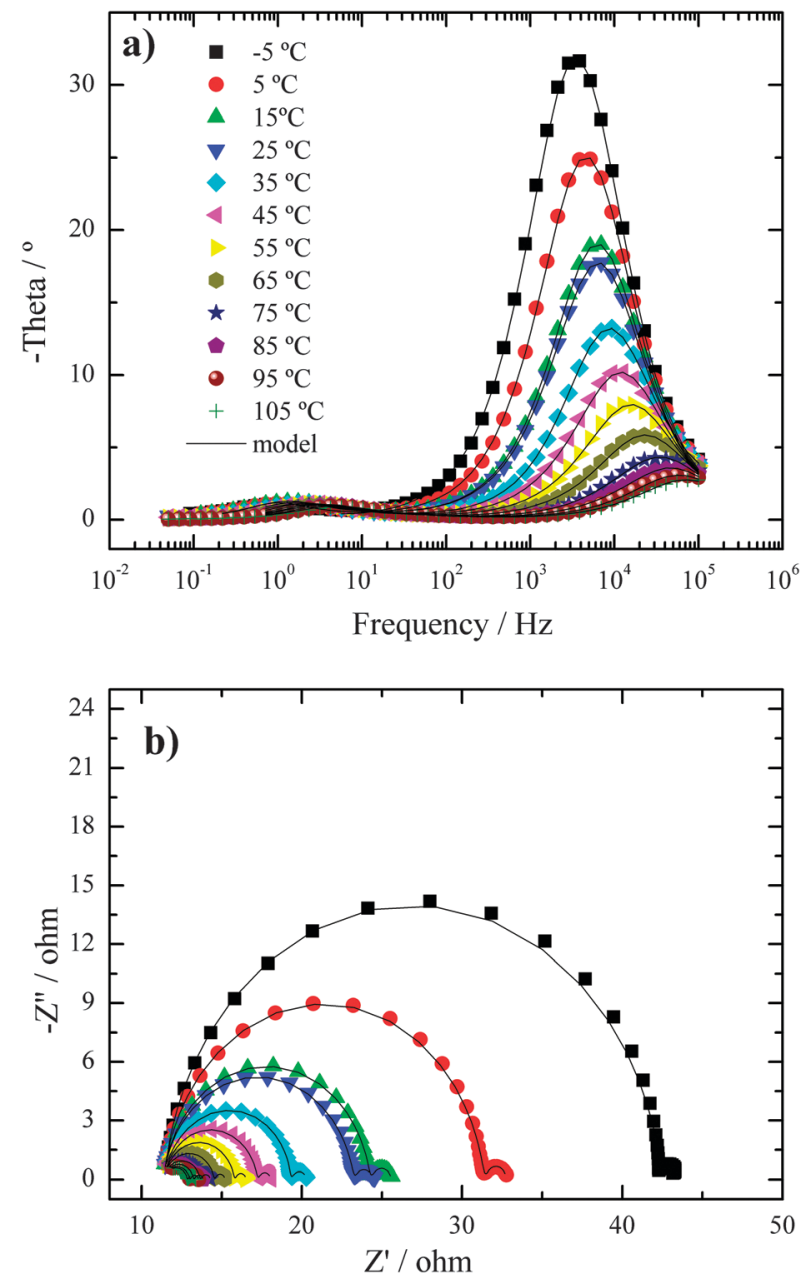

Fig. 7 Platinum half-cell Bode (a) and Nyquist (b) plots obtained in dark conditions at $0 \mathrm{~V}$ in the temperature range -5 to $105^{\circ} \mathrm{C}$.

The DSC efficiency dependence on temperature is normally assigned to the conduction band shifts in the $\mathrm{TiO}_{2}$ photoelectrode, recombination and charge transport processes. ${ }^{22,48,49}$ Temperature controlled EIS experiments were conducted in platinum half cells to characterize the temperature influence at the counter electrode during the operation of the DSCs. Bode and Nyquist diagrams are shown for platinum half cells in Fig. 7, which were obtained at $0 \mathrm{~V}$ and under dark conditions for different temperatures; the electrochemical reaction at the platinum catalyst layer and electrolyte was then assessed. The Bode diagram shows two frequency peaks, one at low frequencies, corresponding to the diffusion of ionic species in the electrolyte $\left(\mathrm{I}^{-}\right.$and $\mathrm{I}_{3}{ }^{-}$), and another at high frequencies, which was due to the electrochemical reaction at the platinum counter electrode with the electrolyte. ${ }^{50-52}$ The operating temperature causes a slight frequency shift in the low frequency peak, and a moderate shift in the high frequency peak occurs, suggesting a larger influence of temperature in the charge transfer process occurring at the Pt/electrolyte interface than in the electrolyte diffusion processes.

This behaviour was also observed in the Nyquist plot (Fig. 7b): the first semicircle corresponds to the resistance 


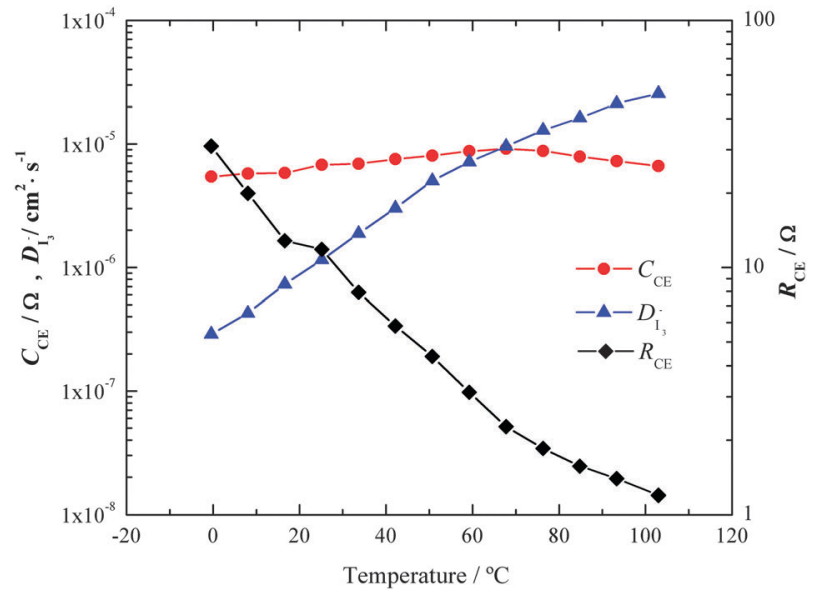

Fig. 8 Impedance data obtained for a platinum half-cell at $0 \mathrm{~V}$ in dark conditions cells in the temperature range studied. Lines were added for readability.

associated with the electrochemical reaction of triiodide to iodide, and the second semicircle to the electrolyte diffusion in the liquid electrolyte. From the Nyquist plot, it can be seen that the first semicircle changes considerably with temperature, whereas the second semicircle changes only slightly. To understand and quantify this influence, the EIS experimental data were fitted to an equivalent electrical analogue based on a Randles-type circuit (presented in Fig. S6, ESI $\dagger$ ), using ZView ${ }^{\mathbb{R}}$ (Scribner Associates Inc.). ${ }^{53,54}$ The fitting results are shown in Fig. 8, wherein the charge transfer resistance $\left(R_{\mathrm{CE}}\right)$, chemical capacitance of the counter electrode $\left(C_{\mathrm{CE}}\right)$, and ionic diffusion coefficient $\left(D_{\mathrm{I}_{3}}\right)$ are plotted against temperature. $R_{\mathrm{CE}}$ displays an exponential trend with temperature as expected from the ButlerVolmer equation; the electrolyte diffusion shows an exponential increase with temperature as well, whereas the electrochemical capacitance of the counter electrode remains relatively constant as the reaction surface area is unchanged by temperature..$^{55}$ These results suggest that temperature has a highly beneficial effect regarding to the counter electrode operation. In DSCs, the electrochemical reaction at the counter electrode is basically the same as that at the photoelectrode when generated electrons react undesirably with the electrolyte species present in the porous film of titanium dioxide; this prejudicial reaction, typically called recombination reaction, is believed to be the main limiting factor of efficiency, not only in DSCs but in the majority of solar technologies. ${ }^{56-58}$ The fundamental difference between both reactions is the source of electrons and the interface wherein the electrochemical reactions take place. At the counter electrode, the triiodide reduction reaction takes place catalysed by a platinized layer applied on the $\mathrm{SnO}_{2}-\mathrm{F}$ substrate; iodine then diffuses to the photoelectrode to regenerate the oxidized dye.

Direct reduction of triiodide may occur at the photoelectrode - external recombination, which limits the total current and voltage and thus the final efficiency of the device. The recombination reaction can occur directly at the $\mathrm{TiO}_{2} /$ electrolyte interface $\left(\mathrm{R}_{1}\right)$ or at the FTO/electrolyte interface $\left(\mathrm{R}_{2}\right)$, as represented in Fig. 1.
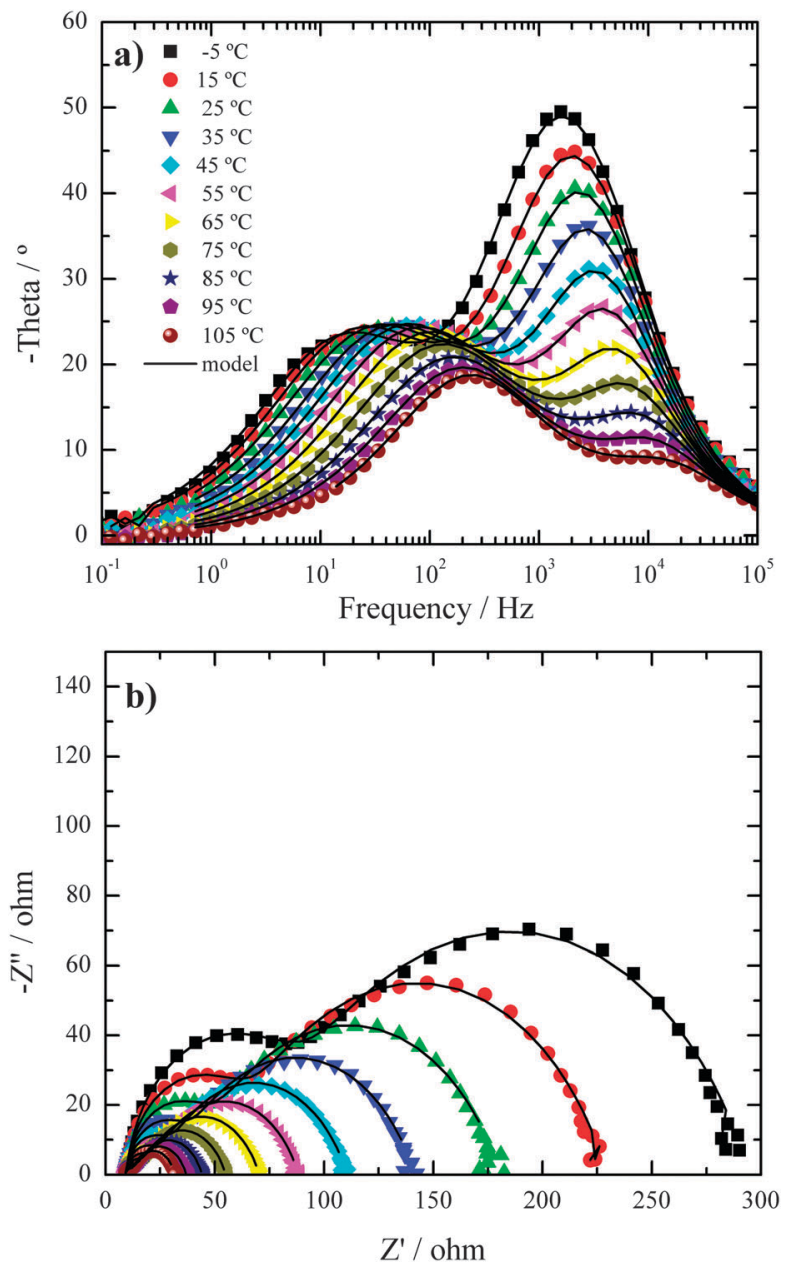

Fig. 9 Complete DSC Bode (a) and Nyquist (b) plots obtained under dark conditions, at the $V_{\mathrm{OC}}$ of the cell at $25^{\circ} \mathrm{C}(-0.78 \mathrm{~V})$ for the temperature range from $5{ }^{\circ} \mathrm{C}$ to $105^{\circ} \mathrm{C}$.

Fig. 9 shows the EIS results of a typical batch of DSCs. The experimental data was fitted using appropriate electrical analogues, namely, using the transmission line model (presented in Fig. S7, ESI $\dagger$ ) ${ }^{59-61}$ This model, proposed by Bisquert et al. ${ }^{44}$ is used widely to describe the transport and recombination kinetic processes in DSCs. The experiments were conducted under dark conditions at the $V_{\mathrm{OC}}$ value obtained at $25^{\circ} \mathrm{C}(0.77 \mathrm{~V})$. The Bode diagram shows two frequency peaks, corresponding to the electron transport and recombination at the photoelectrode (low frequency) and to the reduction reaction occurring at the platinum counter electrode (high frequency). Both the phase peaks shift to higher frequencies as temperature increases; the shift of the high frequency peak in the Bode diagram and the first semicircle in the Nyquist plot indicates that the counter electrode performance improves with temperature.

Looking at the low frequency peak in the Bode diagram (Fig. 9a) and the second semicircle in the Nyquist plot (Fig. 9b), it appears that the electron/electrolyte recombination resistance decreases with temperature. The calculated parameters from model fitting ${ }^{60}$ are plotted against temperature in Fig. 10. Transport and recombination related parameters are the photoelectrode 

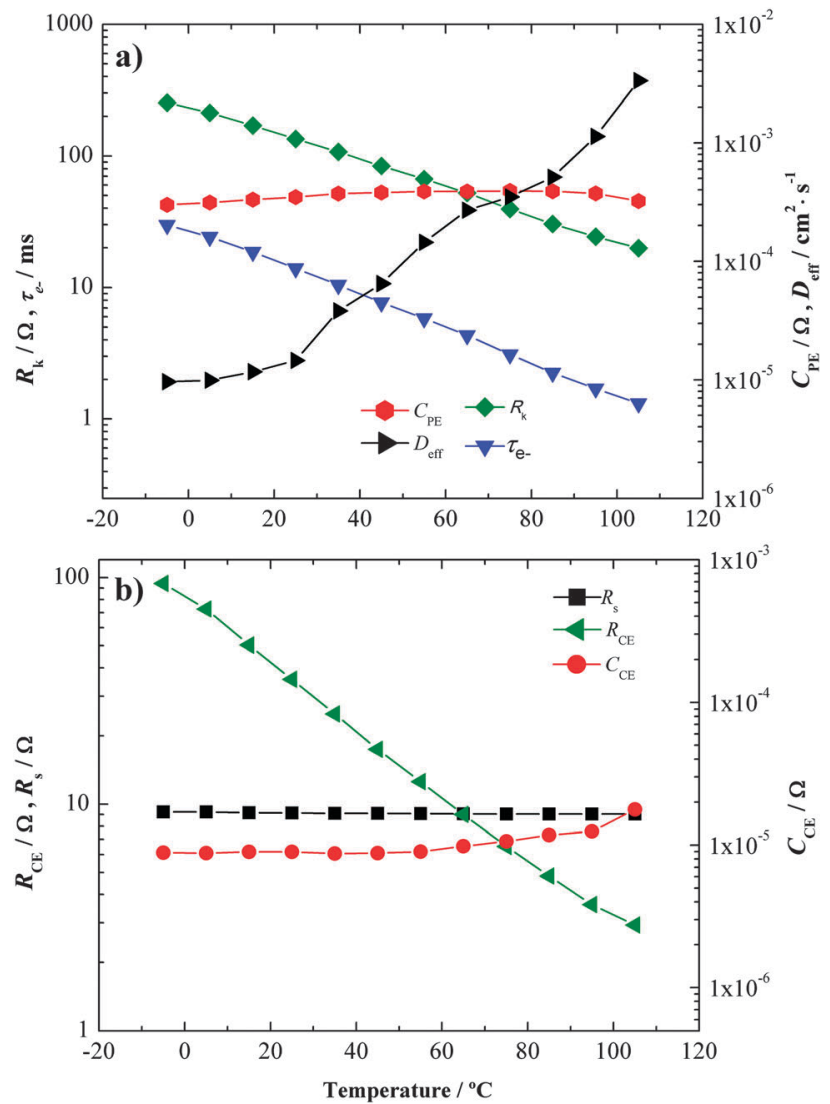

Fig. 10 Impedance parameters obtained by EIS for complete DSCs cells at $0.78 \mathrm{~V}$ under dark conditions for the temperature range studied. Lines were added for readability.

capacitance, $C_{\mathrm{PE}}$, electron diffusion coefficient, $D_{\mathrm{eff}}$, recombination resistance, $R_{\mathrm{k}}$, and electron lifetime, $\tau_{\mathrm{e}^{-}}$. While $C_{\mathrm{PE}}$ appears to be relatively constant due to the unchanged reaction surface area, $R_{\mathrm{k}}$ and $\tau_{\mathrm{e}^{-}}$decrease exponentially with temperature.

This highlights the fact that the recombination reaction is enhanced considerably by temperature. However, electron transport, evaluated by $D_{\text {eff }}$, improves with temperature. Considering that the final performance of the solar cell is a balance between electron generation, recombination and transport, there are two opposite effects caused by temperature. The recombination increases with temperature; however, the electron transport rate also increases with temperature. Assuming that the electron generation rate, conduction band and electrolyte redox potentials are mostly constant with temperature, ${ }^{27}$ in terms of DSC performance, the balance is negative, as seen from the global efficiency vs. temperature results (Fig. 5 and 6). This shows that in terms of temperature dependence, recombination is dominant over charge transport.

\section{Recombination and DSC performance as a function of temperature}

To assess the recombination rate at the $\mathrm{TiO}_{2} /$ electrolyte and FTO/electrolyte interfaces of the solar cell and their temperature dependence, five batches of DSCs were prepared and
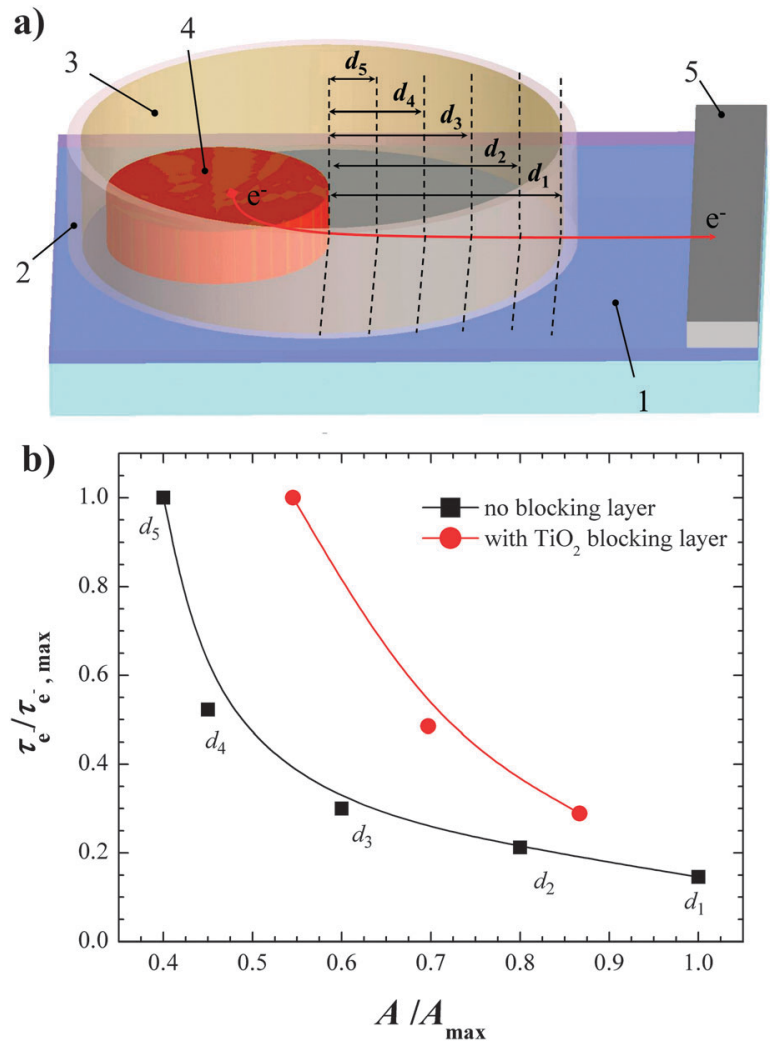

Fig. 11 (a) Schematic showing the methodology to control the FTO/ electrolyte exposed reaction interface in the photoelectrode; 1 - TCO; 2 - glass frit sealing; 3 - electrolyte; $4-\mathrm{TiO}_{2}$ with adsorbed sensitizer; 5 - electrical contact; the dashed lines represent the relative positioning of the glass fir sealing. (b) Experimental results of the electron lifetime versus the exposed area of electrolyte to $\mathrm{FTO}$ or $\mathrm{TiO}_{2}$ blocking layer. Lines were added for readability.

analysed by $I-V$ and EIS characterization. Each batch, of three identical cells, differs in terms of the total recombination rate constant, $k_{\mathrm{r}}(i)$. To experimentally change the total recombination reaction rate constant, $k_{\mathrm{r}}(1)$ to $k_{\mathrm{r}}(5)$, the perimeter length of the glass frit sealing was varied, as displayed by Fig. 11a); all the remaining solar cell design parameters (such as the $\mathrm{TiO}_{2}$ active area and distance to metallic contacts) were kept constant. This way it is possible to change the extent of free TCO area in contact with the electrolyte, and thus the amount of generated electrons that may recombine with triiodide. It should be emphasized that the total distance from the active area to the metallic contact remains constant; therefore, the series resistance in the solar cell is also constant between batches. Because the $\mathrm{TiO}_{2}$ /electrolyte interface is constant for all five batches of cells, it is then possible to assess the temperature effect on the recombination rate constant at the FTO/electrolyte.

Fig. 11(b) plots the electron lifetime against the exposed electrolyte area for the DSCs with and without the $\mathrm{TiO}_{2}$ blocking layer. Indeed, the exposed area affects recombination, even in the case of DSCs with a $\mathrm{TiO}_{2}$ blocking layer applied over the $\mathrm{SnO}_{2}-\mathrm{F}$ film. This illustrates the importance of minimizing the exposed non-active area to the electrolyte, as well as optimizing the blocking layer design. An ideal blocking layer should completely 

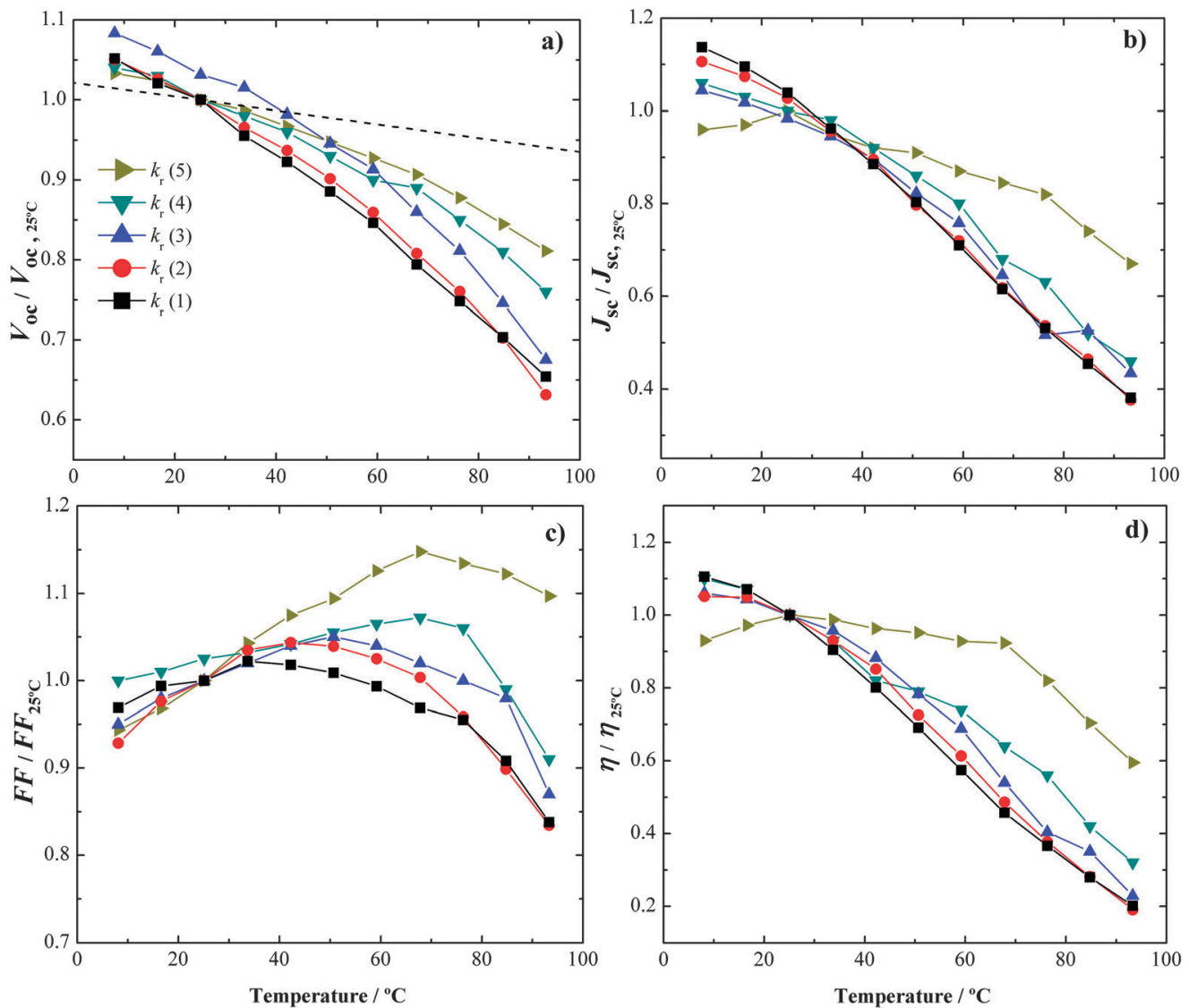

Fig. $12 I-V$ performance parameters $\left(V_{O C}, J_{s c}, F F\right.$ and $\eta, a-d$ respectively) - relative to $25^{\circ} \mathrm{C}$ values of five different batches of DSCs differing in the recombination reaction constant $k_{\mathrm{r}}(i)$. The black dashed line in (a) corresponds to the theoretical $V_{\mathrm{OC}} v s$. temperature trend expected for a cell with no recombination (calculated from the Butler-Volmer equation ${ }^{64}$ ). Lines were added for readability.

prevent recombination, a fact that does not happen according to the results presented in Fig. 11(b). The blocking layer employed was applied by chemical bath deposition of an aqueous $\mathrm{TiCl}_{4}$ solution. Although this is a common method used for preparing high efficient DSCs, this procedure may produce a defected blocking layer. ${ }^{33,62}$

Analysing the $I-V$ parameters (normalized by results at $25{ }^{\circ} \mathrm{C}$ ) for the different DSC batches, Fig. 12 , it is possible to conclude that the trend of each parameter $\left(V_{\mathrm{OC}}, J_{\mathrm{SC}}, \mathrm{FF}\right.$ and $\left.\eta\right)$ depends on the total recombination rate constants; the rate constants were numbered from the highest, $k_{\mathrm{r}}(1)$, to the lowest $k_{\mathrm{r}}(5)$. The results indicate that the total recombination reaction rate increases monotonously with increasing interface area and temperature. This means that although the prepared solar cells at $25{ }^{\circ} \mathrm{C}$ have similar efficiencies $(\sim 5 \%$ to $6 \%)$ when subjected to different operating temperatures, substantial changes in performance emerge. The differences observed in the FF and efficiency are caused by the $V_{\mathrm{OC}}(T)$ and $J_{\mathrm{SC}}(T)$ values. It was expected that $\mathrm{TiO}_{2}$ conduction band down shifts to the electrolyte redox potential, reducing the open circuit voltage. However, this shift causes only a slight change, as seen in Fig. 12(a) (dashed black line, calculated from the Butler-Volmer equation ${ }^{63}$ ). The difference between the normalized open circuit potential values, $V_{\mathrm{OC}}{ }^{*}$, predicted by Butler-Volmer and the observed values was assigned to recombination. On the other hand, $J_{\mathrm{SC}}$ is basically determined by the balance between electron generation and recombination. Assuming that temperature has a negligible effect in the photon absorption and electron generation processes, ${ }^{64,65}$ the trend observed in Fig. 12(b) should be attributed mainly to recombination. It can be concluded that recombination has a greater influence in the $V_{\mathrm{OC}}$ and $J_{\mathrm{SC}}$ evolution with temperature.

The recombination rate constants of the five batches of DSCs were plotted against the inverse of temperature to construct an Arrhenius plot - Fig. 13(a). As expected, the curves corresponding to cells with higher recombination display higher recombination rates. There are clearly two different trends in each curve with a breaking point at $c a .40^{\circ} \mathrm{C}$, which correspond to different activation energies. The activation energies $\left(E_{\mathrm{a}}\right)$ were calculated for each batch of cells, based on two linear fittings. The two $E_{\mathrm{a}}$ values for each batch corresponds to the temperature ranges below $\left(E_{\mathrm{a}, \mathrm{lt}}\right)$ and above $\left(E_{\mathrm{a}, \mathrm{ht}}\right) 40{ }^{\circ} \mathrm{C}$. These values were plotted against the respective rate constants in Fig. 13b. There are two important observations: (i) for both temperature ranges, the activation energies increase with recombination rate; and (ii) $E_{\mathrm{a}, \mathrm{lt}}$ is lower than $E_{\mathrm{a}, \mathrm{ht}}$. This means that more efficient cells, i.e., with less recombination (lower $k_{\mathrm{r}}$ ), have lower activation energy values. This can be explained as 
a)

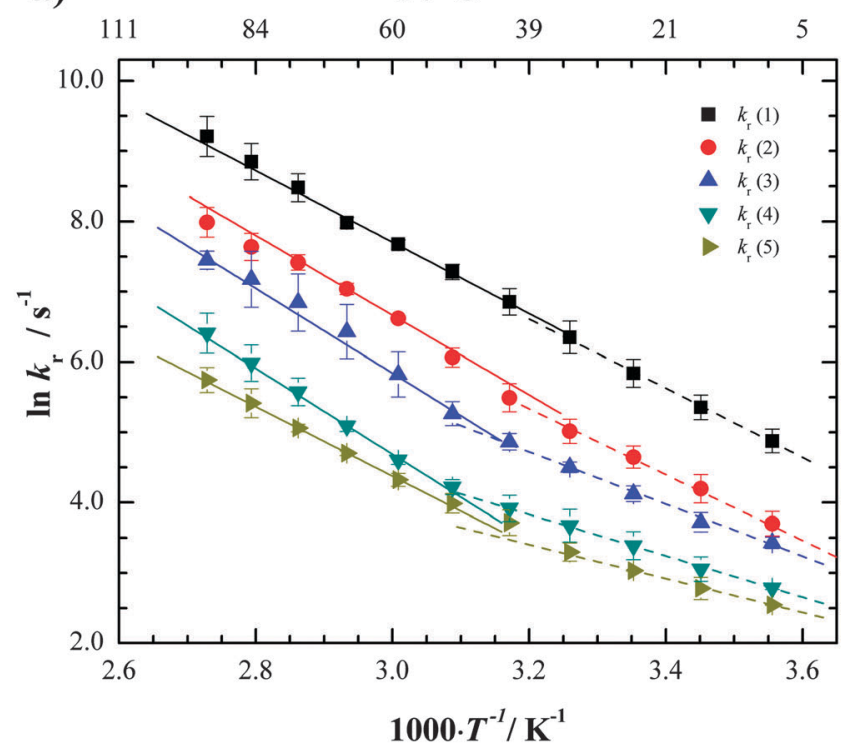

b)

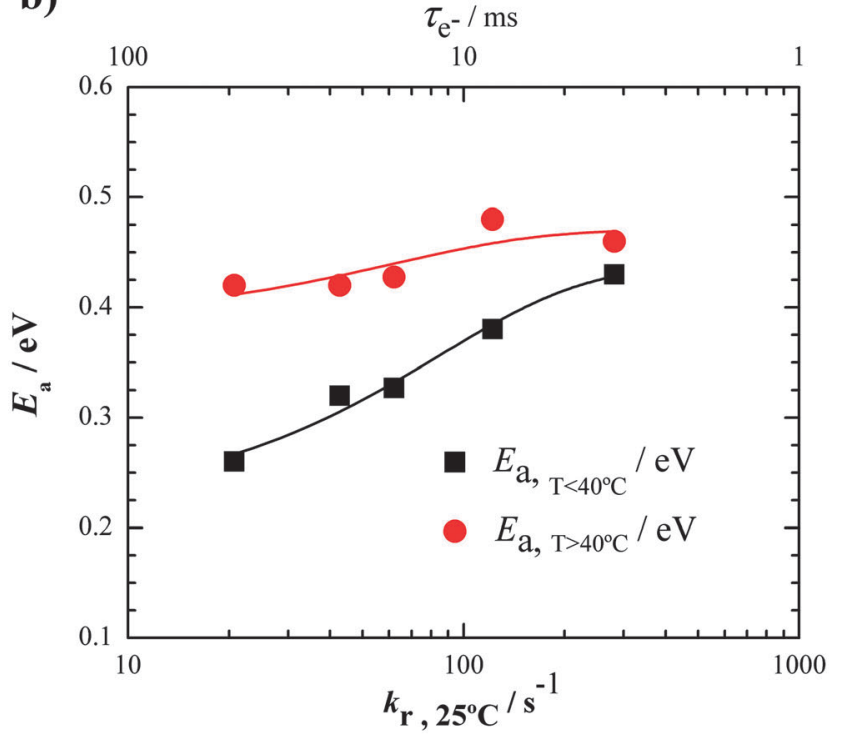

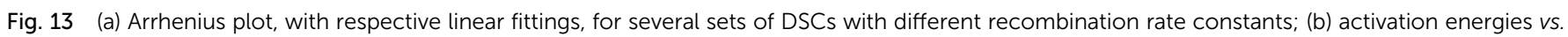

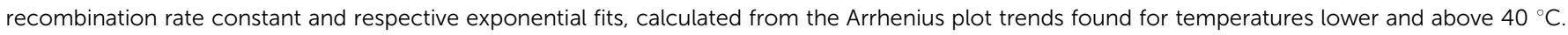

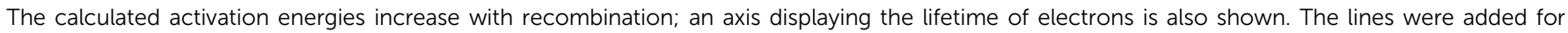
readability.

follows: in this study, to obtain high recombination cells, the TCO interface exposed to the electrolyte was increased as described previously; this means that for high recombination cells (i.e., $k_{\mathrm{r}}(1)$ ), most of the recombination interface is $\mathrm{SnO}_{2}-\mathrm{F}$. In contrast, in low recombination cells (i.e., $k_{\mathrm{r}}(5)$ ), there is almost no FTO exposed, and the main recombination reaction proceeds at the $\mathrm{TiO}_{2}$ interface.

The results suggest that the driving force for the electrochemical reaction between electrons and triiodide is related not only to a reaction rate constant, $k_{\mathrm{r}}(T)$, (that is temperature dependent) and the chemical concentration of triiodide in the electrolyte (that in this case is constant across devices), but also to the energy level of electrons. Given this, when electrons are in a higher energy level (i.e. $\mathrm{TiO}_{2} \mathrm{CB},-4.2 \mathrm{eV}$ (ref. 66)), the activation energy required for recombination is lower compared to electrons in lower energy levels (i.e. $\mathrm{SnO}_{2}-\mathrm{F}$ $\mathrm{CB},-4.7 \mathrm{eV}$ (ref. 66)). This supports the results for the activation energies being lower for $\mathrm{TiO}_{2}$ dominant cells compared with DSCs with a largely exposed TCO. Indeed, these results clearly show that the activation energy barrier rules the recombination process.

Chemical reactions occasionally show an Arrhenius plot with two different linear trends at regions of low and high temperatures. Typically, this feature is associated with simultaneous and competing reactions or reaction mechanisms involving different activation energies, ${ }^{67}$ with one reaction being dominant, depending on the temperature range. In the present case, to understand the two trends of the DSCs recombination reaction Arrhenius plot, half-cells of FTO $\left(\mathrm{SnO}_{2}-\mathrm{F}\right)$, $\mathrm{TiO}_{2}$ and platinum films were prepared and analysed, as described before; the corresponding Arrhenius plot is shown in Fig. 14. As expected, the platinum half-cells show very high reaction rates because platinum is a good catalyst for the reduction reaction of triiodide to iodide. The $\mathrm{SnO}_{2}-\mathrm{F} / \mathrm{SnO}_{2}-\mathrm{F}$ half-cells show two clear distinct trends in the Arrhenius plot. Between $30{ }^{\circ} \mathrm{C}$ and $40{ }^{\circ} \mathrm{C}$, temperature has very little influence on the reaction rate, showing very small activation energy over this temperature range. However, for temperatures higher than $40{ }^{\circ} \mathrm{C}$, there is a good linear fit, resulting in an activation energy of $0.66 \mathrm{eV}$. In the case of $\mathrm{TiO}_{2} / \mathrm{TiO}_{2}$ half-cells, however, the Arrhenius plot does not show multiple trends and the calculated activation energy was found to be $0.47 \mathrm{eV}$.

To rationalize the shape of the Arrhenius plots for recombination in DSCs, as shown in Fig. 13(a), the logarithm of the average rate constants for $\mathrm{SnO}_{2}-\mathrm{F}$ and $\mathrm{TiO}_{2}$ was plotted, as shown in the green curve in Fig. 14. This has a similar shape to the ones from complete DSCs, showing that the influence that temperature has in the recombination process makes a contribution from two distinct recombination mechanisms than can occur at the different interfaces of the solar cell.

The data presented in Fig. 14 shows that at temperatures below $40{ }^{\circ} \mathrm{C}$, temperature has almost no influence on the recombination reaction rate at the TCO interface. This suggests that at low temperature, the main recombination reaction mechanism should be between trapped electrons and electrolyte. $\mathrm{SnO}_{2}-\mathrm{F}$ trap states, located at energies below the conduction band, could be positioned close and even at lower energies than the redox energy of the electrolyte (energies from $\mathrm{SnO}_{2}-\mathrm{F} \mathrm{CB}$ and redox energy of electrolyte are close, ca. -4.7 and $-5.0 \mathrm{eV}$, respectively (ref. 66)), which means that below a certain temperature $\left(40{ }^{\circ} \mathrm{C}\right.$ according to the results of this work), the reaction rate is mostly temperature independent, simply because 


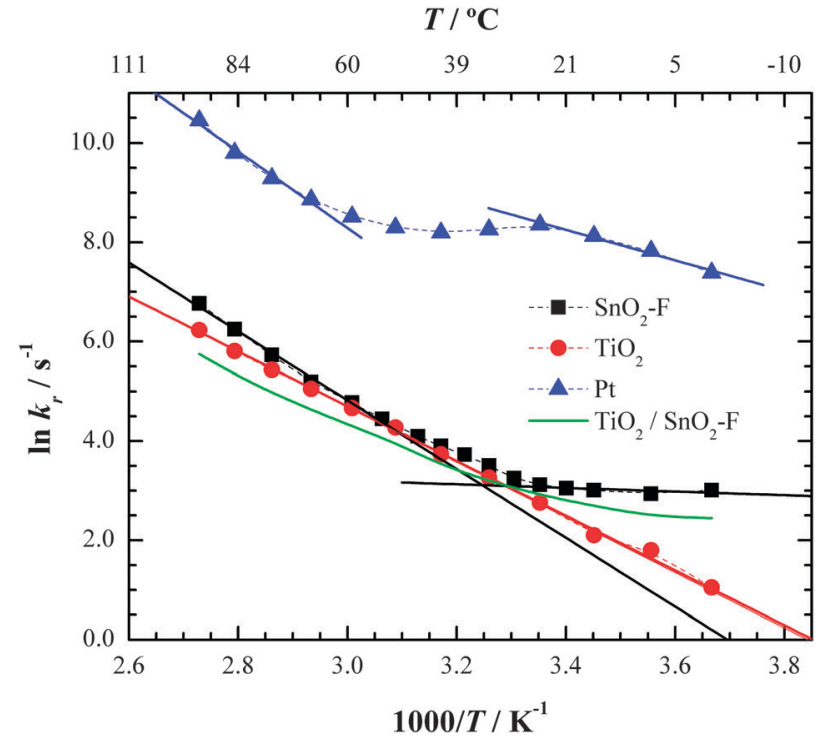

Fig. 14 Arrhenius plot of the recombination reaction (reduction of triiodide) for three types of half-cells: $\mathrm{SnO}_{2}-\mathrm{F}, \mathrm{TiO}_{2}$ blocking layer and $\mathrm{Pt}$. The green curve represents the average between the $\mathrm{TiO}_{2}$ and $\mathrm{SnO}_{2}-\mathrm{F}$ curves.

most electrons do not have sufficient energy to react with the electrolyte. However, in the $\mathrm{TiO}_{2}$ case, owing to its higher conduction band energy $(\sim-4.26 \mathrm{eV})$, most trap states ought to be located above the redox energy of the electrolyte. This means that for the temperature range studied, most trapped electrons should have sufficient energy to react with electrolyte species.

The results suggest that there is a shift in the dominant recombination pathway from trapped electrons to the electrolyte to CB electrons to electrolyte, which explains the different trends in the Arrhenius plots. The recombination reaction mechanism between the CB electrons and electrolyte species requires a lower activation energy; this was confirmed by the activation energies presented in Fig. 13(b). As the total recombination increases (higher $k_{\mathrm{r}}$ in abscissas axis of Fig. 13(b), activation requires progressively more energy due to the trapping energy.

The different shapes found in the Arrhenius plots of the platinum half cells can also be explained considering that the catalyst layer consists of platinum nanoparticles deposited on

Table 1 Recombination rate constants, open-circuit voltages at $25{ }^{\circ} \mathrm{C}$ and activation energies calculated for different batches of complete DSCs and half-cells

\begin{tabular}{llllll}
\hline Device & & $k_{\mathrm{r}}, 25{ }^{\circ} \mathrm{C} / \mathrm{s}^{-1}$ & $V_{\mathrm{OC}}, 25{ }^{\circ} \mathrm{C} / \mathrm{V}$ & $E_{\mathrm{a}, \mathrm{lt}} / \mathrm{eV}$ & $E_{\mathrm{a}, \mathrm{ht}} / \mathrm{eV}$ \\
\hline DSCs & $k_{\mathrm{r}}(1)$ & 281 & 0.719 & 0.43 & 0.46 \\
& $k_{\mathrm{r}}(2)$ & 122 & 0.727 & 0.38 & 0.48 \\
& $k_{\mathrm{r}}(3)$ & 62.1 & 0.734 & 0.33 & 0.43 \\
& $k_{\mathrm{r}}(4)$ & 42.8 & 0.768 & 0.32 & 0.42 \\
& $k_{\mathrm{r}}(5)$ & 20.8 & 0.770 & 0.26 & 0.42 \\
Half-cells & $\mathrm{Pt}$ & 4257 & & & \\
& $\mathrm{SnO}$ & & 0.30 & 0.75 \\
& $\mathrm{SiO}_{2}-\mathrm{F}$ & 22.64 & & 0.0 & 0.66 \\
& $\mathrm{TiO}_{2}$ & & & 0.47 & 0.47
\end{tabular}

TCO; $\mathrm{SnO}_{2}-\mathrm{F}$ crystals exposed to the electrolyte at this surface provide an alternative reaction pathway from the Pt catalyst.

Taking into account the abovementioned considerations, the main results concerning recombination $v$ s. temperature are compiled in Table 1 . The cells with low $k_{\mathrm{r}}$ show a higher $V_{\mathrm{OC}}$ and higher activation energies for the recombination reaction that occurs mainly at $\mathrm{TiO}_{2} /$ electrolyte: $E_{\mathrm{a}, \mathrm{lt}}=0.26 \mathrm{eV}$ and $E_{\mathrm{a}, \mathrm{ht}}=0.42 \mathrm{eV}$; when the main recombination interface is $\mathrm{SnO}_{2}-\mathrm{F} /$ electrolyte (high $k_{\mathrm{r}}$ ), the activation energy was found to be $E_{\mathrm{a}, \mathrm{lt}}=0.43 \mathrm{eV}$ and $E_{\mathrm{a}, \mathrm{ht}}=0.46 \mathrm{eV}$.

\section{Conclusions}

The DSC performance as a function of temperature was assessed for a wide range of temperatures from $-5{ }^{\circ} \mathrm{C}$ to $105{ }^{\circ} \mathrm{C}$. The DSC cells were hermetically sealed using the recently developed laserassisted glass sealing process, which allowed obtaining reliable results. Within the temperature range considered, the degradation of the components of the solar cells was not observed, with full efficiency reversibility (at $25{ }^{\circ} \mathrm{C}$ ) in samples tested up to $100{ }^{\circ} \mathrm{C}$.

The recombination was quantified as a function of temperature and for the $\mathrm{SnO}_{2}-\mathrm{F} /$ electrolyte and $\mathrm{TiO}_{2} /$ electrolyte interfaces. It was concluded that the electrons energy level significantly affects the recombination reaction: when electrons are in a higher energy level (i.e. $\mathrm{TiO}_{2} \mathrm{CB}$ ), the driving force for recombination is lower than the lower energy level electrons (i.e. $\mathrm{SnO}_{2}-\mathrm{F} \mathrm{CB}$ ). Therefore, the activation energy was found to be lower for the recombination taking place at the $\mathrm{TiO}_{2}$ interface than at the $\mathrm{SnO}_{2}-\mathrm{F}$ interface with the electrolyte $(0.47 \mathrm{eV}$ vs. $0.66 \mathrm{eV}$, respectively).

Arrhenius plots for the recombination rates in DSCs showed two different activation energies for temperatures below and above $c a .40{ }^{\circ} \mathrm{C}$. To explain this, the authors propose a shift in the dominant recombination pathway from trapped electrons/ electrolyte to the CB electrons/electrolyte. This study shows that recombination depends on both the temperature and semiconductor interfaces present in the solar cell.

In general, temperature has an overall negative effect on the DSC performance; this effect was shown to be governed by the total electron/electrolyte recombination.

\section{Acknowledgements}

J. Maçaira is grateful to the Portuguese Foundation for Science and Technology (FCT) for his PhD Grant (Reference: SFRH/BD/ 80449/2011) and I. Mesquita acknowledges to Project WinDSC SI\&IDT (ref. 21539/2011) for financial support. L. Andrade acknowledges European Research Council (Contract no. 321315). This study was financially supported by the Project UID/EQU/00511/2013-LEPABE, the FCT/MEC with national funds and when applicable co-funded by the FEDER in the scope of the P2020 Partnership Agreement, the Project NORTE07-0124-FEDER-000026-RL1_Energy, the FEDER funds through Programa Operacional Factores de Competitividade - COMPETE, 
the Programa Operacional do Norte (ON2) program and the national funds through FCT - Fundacapara a Ciencia e a Tecnologia (PTDC/EQU-EQU/120064/2010). Financial support by the European Research Council (Contract no: 321315) is also acknowledged. The authors would like to acknowledge the fruitful suggestions by reviewer \#1, namely, concerning the discussion on the recombination mechanisms.

\section{References}

1 H. Ossenbrink, T. Huld, A. J. Waldau and N. Taylor, Photovoltaic Electricity Cost Maps, 2013.

2 L. M. Goncalves, V. d. Z. Bermudez, H. A. Ribeiro and A. M. Mendes, Energy Environ. Sci., 2008, 1, 655-667.

3 M. K. Nazeeruddin, E. Baranoff and M. Grätzel, Sol. Energy, 2011, 85, 1172-1178.

4 M. Grätzel, J. Photochem. Photobiol., C, 2003, 4, 145-153.

5 M. Ye, X. Wen, M. Wang, J. Iocozzia, N. Zhang, C. Lin and Z. Lin, Mater. Today, 2015, 18, 155-162.

6 Y. Chiba, A. Islam, R. Komiya, N. Koide and L. Han, Appl. Phys. Lett., 2006, 88, 223505.

7 Y. Chiba, A. Islam, Y. Watanabe, R. Komiya, N. Koide and L. Han, Jpn. J. Appl. Phys., Part 1, 2006, 45, L638-L640.

8 M. A. Green, K. Emery, Y. Hishikawa, W. Warta and E. D. Dunlop, Prog. Photovolt.: Res. Appl., 2015, 23, 1-9.

9 A. Yella, H.-W. Lee, H. N. Tsao, C. Yi, A. K. Chandiran, M. K. Nazeeruddin, E. W.-G. Diau, C.-Y. Yeh, S. M. Zakeeruddin and M. Grätzel, Science, 2011, 334, 629-634.

10 J. Burschka, N. Pellet, S.-J. Moon, R. Humphry-Baker, P. Gao, M. K. Nazeeruddin and M. Gratzel, Nature, 2013, 499, 316-319.

11 N. J. Jeon, J. H. Noh, W. S. Yang, Y. C. Kim, S. Ryu, J. Seo and S. I. Seok, Nature, 2015, 517, 476-480.

12 H. Zhou, Q. Chen, G. Li, S. Luo, T.-B. Song, H.-S. Duan, Z. Hong, J. You, Y. Liu and Y. Yang, Science, 2014, 345, 542-546.

13 F. O. Lenzmann and J. M. Kroon, Adv. OptoElectron., 2007, 65073.

14 N. Kato, Y. Takeda, K. Higuchi, A. Takeichi, E. Sudo, H. Tanaka, T. Motohiro, T. Sano and T. Toyoda, Sol. Energy Mater. Sol. Cells, 2009, 93, 893-897.

15 N. Kato, K. Higuchi, H. Tanaka, J. Nakajima, T. Sano and T. Toyoda, Sol. Energy Mater. Sol. Cells, 2011, 95, 301-305.

16 K.-M. Lee, C.-Y. Chen, S.-J. Wu, S.-C. Chen and C.-G. Wu, Sol. Energy Mater. Sol. Cells, 2013, 108, 70-77.

17 M. Flasque, A. N. Van Nhien, J. Swiatowska, A. Seyeux, C. Davoisne and F. Sauvage, ChemPhysChem, 2014, 15, 1126-1137.

18 D. Högberg, B. Soberats, S. Uchida, M. Yoshio, L. Kloo, H. Segawa and T. Kato, Chem. Mater., 2014, 26, 6496-6502.

19 G. Niu, X. Guo and L. Wang, J. Mater. Chem. A, 2015, 3, 8970-8980.

20 T. C. Sum and N. Mathews, Energy Environ. Sci., 2014, 7, 2518-2534.
21 N. Jiang, T. Sumitomo, T. Lee, A. Pellaroque, O. Bellon, D. Milliken and H. Desilvestro, Sol. Energy Mater. Sol. Cells, 2013, 119, 36-50.

22 S. R. Raga and F. Fabregat-Santiago, Phys. Chem. Chem. Phys., 2013, 15, 2328-2336.

23 M. Toivola, L. Peltokorpi, J. Halme and P. Lund, Sol. Energy Mater. Sol. Cells, 2007, 91, 1733-1742.

24 M. Berginc, U. Opara Krašovec, M. Jankovec and M. Topič, Sol. Energy Mater. Sol. Cells, 2007, 91, 821-828.

25 H. Yang, C. Yu, Q. Song, Y. Xia, F. Li, Z. Chen, X. Li, T. Yi and C. Huang, Chem. Mater., 2006, 18, 5173-5177.

26 K. Lobato and L. M. Peter, J. Phys. Chem. B, 2006, 110, 21920-21923.

27 J. S. Henry, S.-M. Lukas, G. Michael and C. Marco, Phys. Rev. B: Condens. Matter Mater. Phys., 2006, 74, 0453061.

28 M. Wang, P. Chen, R. Humphry-Baker, S. M. Zakeeruddin and M. Gratzel, ChemPhysChem, 2009, 10, 290-299.

29 R. Memming, Semiconductor Electrochemistry, Wiley-VCH, 2001.

30 M. Bailes, P. J. Cameron, K. Lobato and L. M. Peter, J. Phys. Chem. B, 2005, 109, 15429-15435.

31 B. O'Regan, L. Xiaoe and T. Ghaddar, Energy Environ. Sci., 2012, 5, 7203-7215.

32 B. C. O'Regan and J. R. Durrant, J. Phys. Chem. B, 2006, 110, 8544-8547.

33 P. J. Cameron and L. M. Peter, J. Phys. Chem. B, 2003, 107, 14394-14400.

34 L. Kavan, N. Tétreault, T. Moehl and M. Grätzel, J. Phys. Chem. C, 2014, 118, 16408-16418.

35 L. Kavan, M. Zukalova, O. Vik and D. Havlicek, ChemPhysChem, 2014, 15, 1056-1061.

36 D. H. Kim, M. Woodroof, K. Lee and G. N. Parsons, ChemSusChem, 2013, 6, 1014-1020.

37 J. Xia, N. Masaki, K. Jiang and S. Yanagida, J. Phys. Chem. B, 2006, 110, 25222-25228.

38 H.-J. Son, C. Prasittichai, J. E. Mondloch, L. Luo, J. Wu, D. W. Kim, O. K. Farha and J. T. Hupp, J. Am. Chem. Soc., 2013, 135, 11529-11532.

39 K.-I. Jang, E. Hong and J. Kim, Korean J. Chem. Eng., 2012, 29, 356-361.

40 C. Jiang, W. L. Koh, M. Y. Leung, W. Hong, Y. Li and J. Zhang, J. Solid State Chem., 2013, 198, 197-202.

41 W. Yongzhen, Y. Xudong, C. Han, Z. Kun, Q. Chuanjiang, L. Jian, P. Wenqin, I. Ashraful, B. Enbing, Y. Fei, Y. Maoshu, Z. Peng and H. Liyuan, Appl. Phys. Express, 2014, 7, 052301.

42 B. C. O'Regan, J. R. Durrant, P. M. Sommeling and N. J. Bakker, J. Phys. Chem. C, 2007, 111, 14001-14010.

43 F. d. r. Sauvage, D. Chen, P. Comte, F. Huang, L.-P. Heiniger, Y.-B. Cheng, R. A. Caruso and M. Graetzel, ACS Nano, 2010, 4, 4420-4425.

44 J. Bisquert, J. Phys. Chem. B, 2002, 106, 325-333.

45 J. Bisquert, J. Electroanal. Chem., 2010, 646, 43-51.

46 F. Ribeiro, J. Maçaira, R. Cruz, J. Gabriel, L. Andrade and

A. Mendes, Sol. Energy Mater. Sol. Cells, 2012, 96, 43-49.

47 PCT/IB2012/051376, PCT/IB2012/051376, 2012.

48 A. Usami, S. Seki, Y. Mita, H. Kobayashi, H. Miyashiro and N. Terada, Sol. Energy Mater. Sol. Cells, 2009, 93, 840-842. 
49 H. J. Snaith and L. Schmidt-Mende, Adv. Mater., 2007, 19, 3187-3200.

50 L. Andrade, J. Sousa, H. A. Ribeiro and A. Mendes, Sol. Energy, 2011, 85, 781-793.

51 R. Cruz, D. A. Pacheco Tanaka and A. Mendes, Sol. Energy, 2012, 86, 716-724.

52 F. Fabregat-Santiago, J. Bisquert, G. Garcia-Belmonte, G. Boschloo and A. Hagfeldt, Sol. Energy Mater. Sol. Cells, 2005, 87, 117-131.

53 R. Cruz, J. P. Araujo, L. Andrade and A. Mendes, J. Mater. Chem. A, 2014, 2, 2028-2032.

54 A. Hauch and A. Georg, Electrochim. Acta, 2001, 46, 3457-3466. 55 J. Bisquert, Phys. Chem. Chem. Phys., 2003, 5, 5360-5364.

56 H. J. Snaith, Adv. Funct. Mater., 2010, 20, 13-19.

57 B. E. Hardin, H. J. Snaith and M. D. McGehee, Nat. Photonics, 2012, 6, 162-169.

58 J. Maçaira, L. Andrade and A. Mendes, Renewable Sustainable Energy Rev., 2013, 27, 334-349.
59 J. Bisquert, M. Gratzel, Q. Wang and F. Fabregat-Santiago, J. Phys. Chem. B, 2006, 110, 11284-11290.

60 L. Andrade, S. M. Zakeeruddin, M. K. Nazeeruddin, H. A. Ribeiro, A. Mendes and M. Grätzel, ChemPhysChem, 2009, 10, 1117-1124.

61 Q. Wang, J.-E. Moser and M. Grätzel, J. Phys. Chem. B, 2005, 109, 14945-14953.

62 B. Yoo, K.-J. Kim, S.-Y. Bang, M. J. Ko, K. Kim and N.-G. Park, J. Electroanal. Chem., 2010, 638, 161-166.

63 J. Macaira, L. Andrade and A. Mendes, RSC Adv., 2014, 4, 2830-2844.

64 M. Grätzel, Prog. Photovolt.: Res. Appl., 2000, 8, 171-185.

65 M. Grätzel and J.-E. Moser, in Electron Transfer in Chemistry, ed. V. Balzani, Wiley-VCH, Weinheim, 2001, vol. 5, ch. 3.

66 R. Memming, Semiconductor Electrochemistry, Wiley-VCH Verlag GmbH, 2007, pp. 241-263.

67 L. Masgrau, À. González-Lafont and J. M. Lluch, Theor. Chem. Acc., 2003, 110, 352-357. 